\title{
Chemically Enhanced Primary Treatment-Trickling Filter with Moringa oleifera Seeds for Improved Energy Recovery from Wastewater Treatment Plants in Malawi
}

\author{
Chimwemwe Mndelemani, Yinling Song, Fankai Wei, Ya Chen \\ School of Environmental Science and Engineering, Suzhou University of Science and Technology, Suzhou, China \\ Email address: \\ cjmndelemani@yahoo.com(C.Mndelemani),ylsong@mail.usts.edu.cn (Yinling Song),wfk9710@163.com (Fankai Wei), \\ m15862351567@163.com(Ya Chen)
}

\author{
To cite this article: \\ Chimwemwe Mndelemani, Yinling Song, Fankai Wei, Ya Chen. Chemically Enhanced Primary Treatment-Trickling Filter with Moringa \\ oleifera Seeds for Improved Energy Recovery from Wastewater Treatment Plants in Malawi. International Journal of Environmental \\ Protection and Policy. Vol. 6, No. 2, 2018, pp. 26-31. doi: 10.11648/j.ijepp.20180602.11
}

Received: March 22, 2018; Accepted: April 15, 2018; Published: May 21, 2018

\begin{abstract}
Only 10\% of the population in Malawi has access to electricity and there is increasing surface water pollution especially in urban areas. This research was conducted with the objectives of improving electricity generation and reducing water pollution in Malawi. A chemically enhanced primary treatment-trickling filter (CEPT-TF) system with Moringa oleifera (MO) seeds as a coagulant is proposed for municipal wastewater (WW) treatment to achieve both objectives. CEPT improves energy recovery by increasing the proportion of captured raw COD whose anaerobic digestion gives higher $\mathrm{CH}_{4}$ yield than secondary COD. The COD removal efficiency of MO was investigated by conducting jar tests and COD tests using WW samples from three different WWTPs in Suzhou New District, China. The amount of energy recoverable was estimated using an equation derived from COD removal efficiencies and the stoichiometric relationships between $\mathrm{COD}$ and $\mathrm{CH}_{4}$. The results showed a COD removal efficiency of $74 \%$ with MO concentration of $50 \mathrm{mg} / 1$ for $880 \mathrm{mg} / \mathrm{l} \mathrm{COD}$ which is an average COD for municipal WW in Malawi. It is found that the WWTPs in Malawi's two big cities of Blantyre and Lilongwe have the potential of producing 9,781.86kWh/d of electricity. CEPT-TF will offer sustainable solutions in Malawi, MO can be planted on sites creating closed loop systems as it provides the coagulant and gets watered and nourished with the effluent from the WWTP.
\end{abstract}

Keywords: Anaerobic Digestion, Energy Self-Sufficiency, Carbon Capture, Chemically Enhanced Primary Treatment, Moringa oleifera

\section{Introduction}

Access to electricity in Malawi is a growing challenge affecting many sectors of development and the social welfare of the citizenry. Only $10 \%$ of the total population has access to electricity with less than $1 \%$ of the rural population [1]. Hydropower is the major source of electricity in the country and is not resilient to the woes of climate change. The effects of this have already been experienced including in 2017 when decreased flows of the Shire River, from which $98 \%$ of the power is generated [2], caused a reduction in electricity generation from about $300 \mathrm{MW}$ to $150 \mathrm{MW}$ [3]. Power supply reduction results into massive load shading affecting people's livelihoods. This necessitates the need for exploring alternative sources of electricity. Access to clean, reliable, reasonably-priced and sustainable energy supply is central to maintaining and improving the living standards of people in Malawi [4].

More WWTPs are expected to be developed in Malawi as there is rapid population growth (which is projected at $31,191,010$ in 2036 doubling that of 2016 [5]), high urbanization and increased industrialization. It is observed that the country has expanded its water supply facilities since attaining independence in 1964 but only little has been done on wastewater treatment facilities. Poor industrial and domestic wastewater disposal is therefore inevitable especially in urban areas. With increasing environmental concerns, pressure is growing demanding better management of wastewater and water pollution control. Conventionally, high efficient WWTPs demand high electricity, this is 
challenged by the unreliable power the country continues to experience, energy self-sufficient WWTPs provide hope in such cases. Since construction of an energy self-sufficient WWTP requires far much higher capital than for a traditional one [6], there is need to develop the most applicable technologies based on environmental and social economic factors in the country so as to optimize energy and treatment efficiencies for future WWTPs in the country. In that regard, CEPT-TF with MO seeds appears to be an excellent option for Malawi, Figure 2.

Table 1. Average wastewater influent and effluent quality in selected WWTPs in Malawi [7, 8 and 9].

\begin{tabular}{|c|c|c|c|c|c|c|}
\hline Plant Name & Flow $\left(\mathrm{m}^{3} / \mathrm{d}\right)$ & Type & COD (mg/l) & BOD (mg/l) & TSS (mg/l) & $\mathrm{NO}_{3}(\mathrm{mg} / \mathrm{l})$ \\
\hline \multirow{2}{*}{ Blantyre WWTP } & \multirow{2}{*}{7,950} & Influent & $1,166.7$ & 475.3 & 210.0 & 64.6 \\
\hline & & Effluent & 597.0 & 244.0 & 129.0 & 92.6 \\
\hline \multirow{2}{*}{ Soche WWTP } & \multirow{2}{*}{6,240} & Influent & 895.2 & 625.0 & 98.5 & 22.8 \\
\hline & & Effluent & 544.0 & 29.4 & 54.8 & 114.2 \\
\hline \multirow{2}{*}{ Limbe WWTP } & \multirow{2}{*}{2,850} & Influent & 1058.7 & 803.0 & 244.2 & 33.5 \\
\hline & & Effluent & 549.0 & 56.8 & 115.0 & 24.1 \\
\hline \multirow{2}{*}{ Kauma WWTP } & \multirow{3}{*}{16,000} & Influent & 432.0 & 117.0 & 130.0 & 31.0 \\
\hline & & Effluent & 87.0 & 16.6 & 57.9 & 26.9 \\
\hline Discharge Limits & & & 60 & 20 & 30 & 50 \\
\hline
\end{tabular}

In Malawi, it would be helpful if implementation of water supply projects considered the treatment of the wastewater to be generated. This would decrease pressure on the existing WWTPs as it is evident that most of the plants have now reached their design capacities and are struggling to meet discharge standards, Table 1. Excellent wastewater treatment services would also encourage the development of wet manufacturing industries in the country. The adoption of CEPT-TF using MO seems to be sustainable in the country as $\mathrm{MO}$ is locally grown and sold at an affordable price compared to other coagulants such as ferric chloride $\left(\mathrm{FeCl}_{3}\right)$. In addition, since most sites have abundant land, the crop can be cultivated on sites. This would result in a closed loop system as shown in Figure 1.

\section{CEPT-Trickling Filter WWTP for Energy Recovery}

Chemically enhanced primary treatment involves the addition of chemicals and/or polymers to promote increased contact between particles prior to primary sedimentation [10]. This increases the efficiency of sedimentation tanks. Typical conventional primary clarifiers achieve a TSS removal of $40-60 \%$ and $\mathrm{BOD}_{5}$ reduction of $20-40 \%$ [11]. In CEPT, it is reported that $\mathrm{FeCl}_{3}$ optimal doses between 40$50 \mathrm{ppm}$ removes $90-100 \%$ TSS and $65-85 \%$ COD [12]. In systems that use artificial aeration, the increased proportion of captured COD in the primary processes helps reduce energy usage for bio-oxidation of the remaining organics in secondary treatment due to reduced organic load [13]. Primary COD is more anaerobically biodegradable than humus sludge [14] resulting into higher $\mathrm{CH}_{4}$ yield for more energy production. The use of trickling filters reduces energy consumption and they are easy to operate.

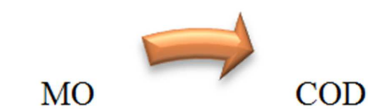

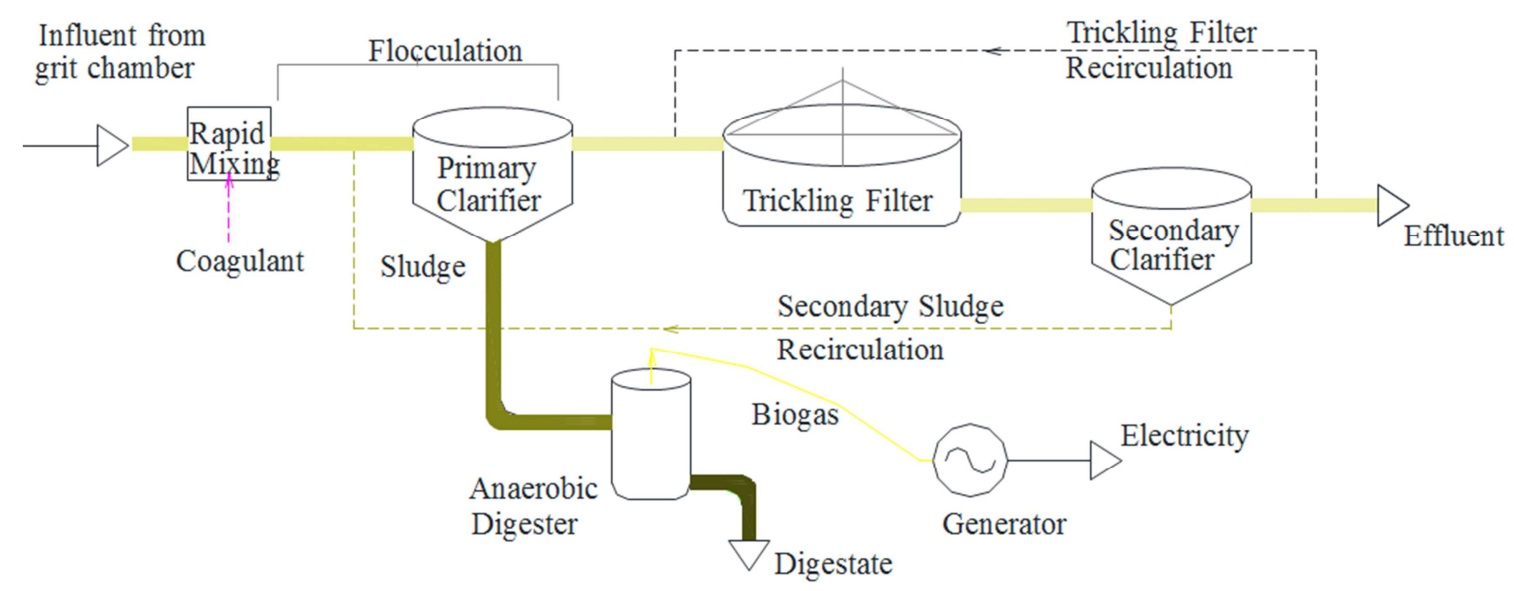

Figure 2. CEPT-TF system. 


\section{CEPT Effect on Energy Recovery}

In practice the conventional activated sludge wastewater treatment systems have a COD removal efficiency of around $40 \%$ in the primary clarifiers, of the remaining $60 \% \mathrm{COD}$, $20 \%$ is removed from the secondary clarifiers to anaerobic digesters. During anaerobic digestion, it is found that $65 \%$ COD in primary sludge is converted to biogas and secondary sludge achieves $35 \%$ COD conversion [15]. To appreciate the impact of CEPT on recoverable energy in WWTPs, the potential chemical energy in wastewater (Ep), the traditionally recoverable energy (Er) and the energy that can be recovered using CEPT ( $\mathrm{E}_{\mathrm{CEPT}}$ ) can be compared by plotting energy $\left(\mathrm{kWh} / \mathrm{m}^{3}\right)$ against COD $(\mathrm{mg} / \mathrm{l})$, Figure 3. Energy potential of the organic matter contained in wastewater is found from $3.5 \mathrm{kWh} / \mathrm{kgCOD}$ [14]. From observed COD removal efficiencies in typical conventional activated sludge WWTPs, it can be assumed that of the COD that enters the secondary treatment process, $50 \%$ is converted to $\mathrm{CO}_{2}, 33.3 \%$ is removed from the secondary clarifiers to the anaerobic digesters and $16.7 \%$ is lost in the effluent. These three processes share the COD escaping primary sedimentation tanks in the ratio $3: 2: 1$ respectively. In this way if CEPT removed $60 \% \mathrm{COD}$, then the COD removed from the secondary clarifiers to the anaerobic digesters would be $(40 \times 0.333)=13.3 \%$. The energy values are estimated from the product of the sum of net COD destruction of primary and secondary sludge and $3.5 \mathrm{kWh} / \mathrm{kgCOD}$ multiplied by the methane to electricity conversion efficiency of gas generators, generally $35 \%$. Thus:

$E_{r}=\left(0.65 E_{C O D p}+0.35 E_{C O D S}\right) 3.5 \times 10^{-3} \operatorname{COD} \times \frac{35}{100}\left(\mathrm{kWh} / \mathrm{m}^{3}\right)$

Where $E_{\text {CODp }}$ and $E_{\text {CODs }}$ are percentage removals of COD from primary and secondary clarifiers to anaerobic digesters, typically $40 \%$ and $20 \%$ respectively. The $10^{-3}$ is for converting the influent COD from $\mathrm{mg} / \mathrm{l}$ to $\mathrm{kg} / \mathrm{m}^{3}$. For Ep, a $100 \%$ COD conversion to methane is assumed, Ercept assumes $\mathrm{E}_{\mathrm{CODp}}$ of $60 \%$, and $\mathrm{E}_{\mathrm{CODs}}$ of $13.3 \%$.

From Figure 3, it can be observed that CEPT has increased the amount of energy recovered from the system by $32.3 \%$. If more efforts could be applied to capture even more COD in primary sedimentation tanks, higher energy yield would be realized, but caution need be taken that the COD concentration of primary effluent is not below the requirements for biological treatment.

Conditions in Malawi favour trickling filters designed for carbon oxidation using natural air draft. These produce effluents with BOD concentrations between 15 and 30mg/l [16] which include the effluent BOD discharge limit for Malawi of 20mg/1 [9]. Furthermore, some lab scale trickling filters have been reported to achieve more than $84 \%$ COD removals [17] and [18].

\section{Moringa oleifera Seeds as a Coagulant}

Moringa oleifera is a tropical plant from the family of Moringacease [19]. Moringa seeds consist of proteins that are water-soluble cationic coagulants [20], the proteins are mainly composed of a $2 \mathrm{~S}$ albumin [21]. Research conducted on the isolated Moringa flocculants showed that the main contributors to clarification are the basic polypeptides with molecular weights between 6,000 and 16,000 Daltons [22]. The coagulation mechanism consists of adsorption and neutralization of the negatively charged impurities in water [22]. Cost and other setbacks associated with the use of chemical coagulants including lowering water $\mathrm{pH}$ [23], put $\mathrm{MO}$ at an exceeding advantage. MO prevents the growth of coliforms, sodomonas and aeroginosen [24], this reduces potential health risks to downstream communities that make use of water bodies into which effluent is discharged. As MO is organic, its sludge can be anaerobically digested thereby increasing biogas yield unlike the use of chemical coagulants. Table 2 presents some properties of MO.

Table 2. Chemical properties of Moringa oleifera seed [20].

\begin{tabular}{ll}
\hline Property & Proportion (\%) \\
\hline Protein & 36.90 \\
Fat & 37.25 \\
Carbohydrates & 16.38 \\
Crude Fiber & 12.85 \\
Moisture & 6.41 \\
Ash & 3.06 \\
\hline
\end{tabular}

\section{Determining COD Removal Efficiency of Moringa oleifera Seeds}

A jar test was conducted to determine the efficiency of $\mathrm{MO}$ in removing COD from wastewater by coagulation and settlement. Water samples were collected from three WWTPs in Suzhou New District located in Jiangsu Province, China and MO seeds were commercially purchased.

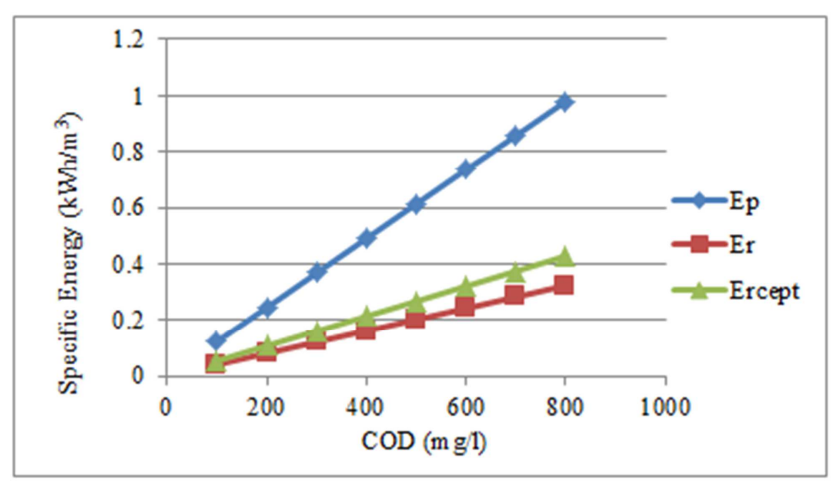

Figure 3. Effect of CEPT on electric energy recovery in WWTPS.

\section{Methodology}

MO 1\% solution was prepared by de-husking the seeds through gentle grinding to prevent damage to the knells, the seed knells were then ground using a lab mortar and pestle and the powder was sieved through a $500 \mu \mathrm{m}$ sieve. $10 \mathrm{~g}$ of the powder was added to $1 \mathrm{~L}$ distilled water and the mixture 
was stirred thoroughly using a magnetic stir.

The Jar Test was carried out using six beakers of $500 \mathrm{ml}$ into which wastewater samples were placed and $\mathrm{MO}$ solutions of $2.5 \mathrm{ml}, 5 \mathrm{ml}, 7.5 \mathrm{ml}, 10 \mathrm{ml}$ and $12.5 \mathrm{ml}$ added into five beakers after the samples were stirred at an initial speed of $100 \mathrm{rev} / \mathrm{min}$ for 30 seconds. Then the speed was adjusted to $30 \mathrm{rev} / \mathrm{min}$ for 30 minutes and samples left to settle for 40minutes. One beaker was left without MO.

COD was determined in the decanted wastewater samples and the raw wastewater using the closed reflux method with $16 \times 100 \mathrm{~mm}$ borosilicate culture tubes and a spectrophotometer. Eight tubes were used, six from the jar test, one had the raw wastewater, and another tube had distilled water to act as a control. All the reagents were added into the borosilicate tubes using micro-burettes.

\section{Results}

The COD removal efficiency of MO appeared to be proportional to the concentration of COD in the wastewater and there was an optimum concentration at which the COD removal started to decline. Similar behavior was observed by Feria Diaz et. al who found that the efficiency of MO in removing turbity was greater in high turbid waters, though there was no optimum point beyond which it started decreasing [25]. As observed, the sample with the lowest COD, $178.7 \mathrm{mg} / \mathrm{l}$, showed a removal efficiency of $40 \%$ for zero dosage of $\mathrm{MO}$ and of $78 \%$ for $12.5 \mathrm{ml}$ of MO. The highest removal efficiencies were observed in the sample with a COD concentration of $758 \mathrm{mg} / 1$ in which the sample that had $7.5 \mathrm{ml}$ dosage gave the highest removal efficiency (90.6\%). The results for COD removal efficiency in samples with zero MO solution are plotted against COD in Figure 4.

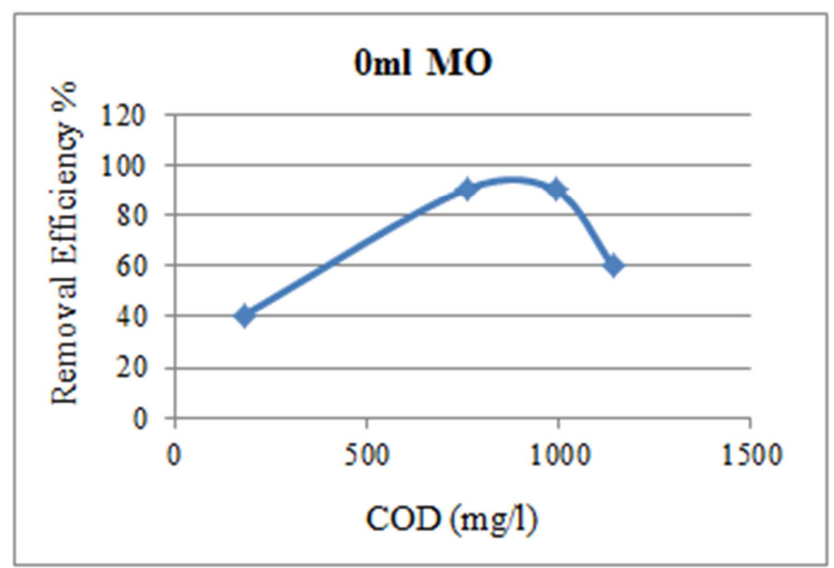

Figure 4. COD removal efficiency with increased COD without coagulant

The sample with zero MO showed $90.5 \%$ COD removal for $758 \mathrm{mg} / 1 \mathrm{COD}$ concentration. This may suggest that at such COD concentrations, high removal efficiencies would be achieved without the use of any coagulant but with only excellent mixing and flocculating processes. This is advantageous for the typical wastewaters in Malawi with average COD values of around $880 \mathrm{mg} / \mathrm{l}$. Nevertheless, relying on the mixing facilities alone would be challenged by energy needs, thus a combination of mixing using hydraulic structures with optimum MO doses would assist in the attainment of higher COD removal efficiencies in Malawi. It can be illustrated that almost all dosages of MO converge with increased COD values, supporting the observation made that high removal efficiency is achieved with higher COD values, Figure 5.

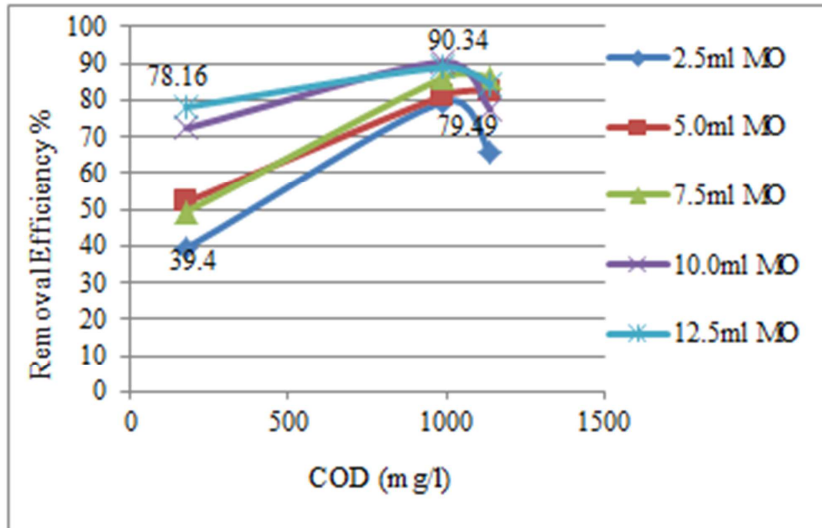

Figure 5. COD removal efficiency of $M O$.

From the test it can be concluded that for the municipal wastewater in Malawi, with COD averaging around $880 \mathrm{mg} / \mathrm{l}$, the suitable MO dose lies between $2.5 \mathrm{ml}$ and $7.5 \mathrm{ml}$ which represents $50 \mathrm{mg} / 1$ to $150 \mathrm{mg} / 1$ respectively. From Figure 5, it is noted that using $\mathrm{MO}$ of $50 \mathrm{mg} / \mathrm{l}$ for a COD concentration of around $880 \mathrm{mg} / 1$ and by linear interpolation, the removal efficiency is around $74 \%$. This would leave a COD concentration of roughly $220 \mathrm{mg} / \mathrm{l}$ for the biological treatment processes which is feasible. However, such removal efficiency is quite higher compared to previous studies that found removal efficiency of $17 \%$ for COD concentration of $435 \mathrm{mg} / 1$ [26].

\section{Evaluating the Energy Potential of WWTPs in Malawi}

In Malawi, the electrical energy potential of municipal WWTPs in the main two Cities of Blantyre and Lilongwe can be estimated from the average COD and the average daily flows using Equation 1. For convenience, the equation will be slightly modified to count for different treatment systems and also allowing for COD loss through carbon dioxide. In this case, $70 \%$ of the removed COD will undergo anaerobic digestion. Thus $\mathrm{E}_{\mathrm{CODp}}+\mathrm{E}_{\mathrm{CODs}}=0.7(\mathrm{COD} \%$ removed $)$ and the average coefficients $(65 \%+35 \%) / 2=50 \%$. For Blantyre WWTP with a $49 \%$ COD removal efficiency and an average COD of $1,166.7 \mathrm{mg} / \mathrm{l}$ (Table 1), this results into:

$$
\begin{gathered}
E_{r}=35 \times 10^{-9} \times 35(50 \times 0.7 \times 49) \times 1,166.7 \\
E_{r}=0.245 \mathrm{kWh} / \mathrm{m}^{3}
\end{gathered}
$$

With a flow of $7,950 \mathrm{~m}^{3} / \mathrm{d}$, daily electricity generation would be $0.245 \times 7,950=1,947.75 \mathrm{kWh}$. In a similar manner the electric energy potential for the other three plants can be estimated, the results are presented in Figure 6. In total, at the 
current treatment efficiencies, the WWTPs have the potential of supplying $5,872.57 \mathrm{kWh} / \mathrm{d}$ to the nation. If the treatment efficiencies were increased to comply with COD effluent discharge permit the total recoverable electric energy would be $9,781.86 \mathrm{kWh} / \mathrm{d}$ which is $66.57 \%$ more. With the high potential for wastewater treatment plants, new plants will have to be designed in a way that would make energy recovery feasible.

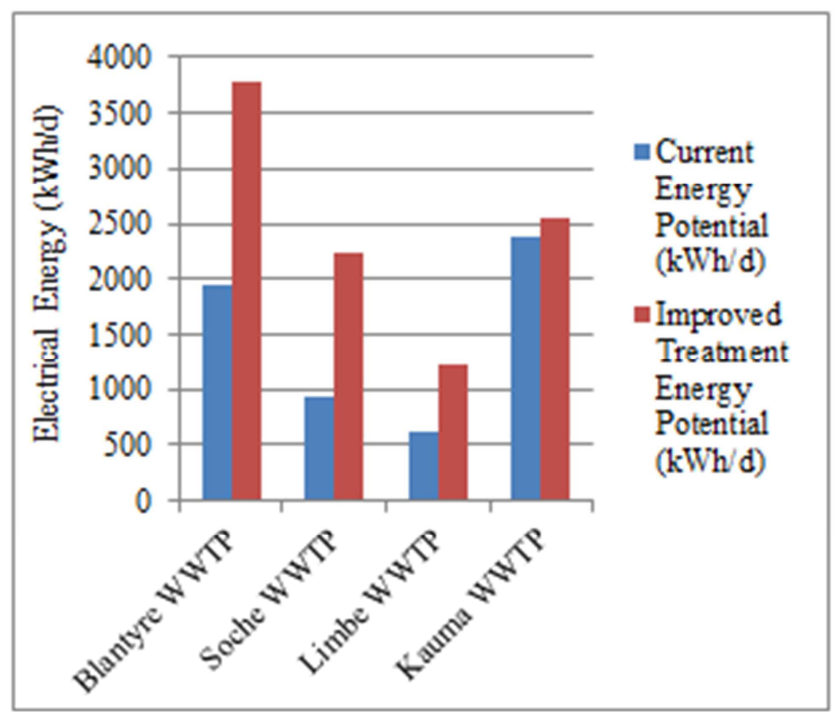

Figure 6. Electric energy potential of WWTPS in Malawi for the current situation and for improved treatment.

\section{Conclusion}

Malawi being a tropical country with high strength wastewaters having temperatures of above $20^{\circ} \mathrm{C}$, possesses excellent environmental conditions for anaerobic treatment processes necessary for biogas production. The abundance of land and availability of $\mathrm{MO}$ as a natural coagulant make the use of CEPT-TF feasible and economical allowing significant energy recovery and efficient treatment.

\section{References}

[1] Phiri, E., Rowley, P., \& Blanchard, R. (2017). Meeting the water and energy needs in the rural areas of Malawi using solar PV technologies. 40th WEDC International Conference. Loughborough.

[2] Long, S. T., Kingdom, K., Leonard, M., Navarro, V. A., Simon, B., Yacob, M., et al. (2017). Policy perspectives on expanding cogeneration from bagasse in Malawi. Journal of Energy in Southern Africa, 45-53.

[3] Nation Publication Limited (NPL). (2017, November 1). Nation Publication Limited (NPL). Retrieved April 12, 2018, from THE NATION: http://mwnation.com/from-bad-to-worse/

[4] Malawi Government. (2017). Malawi Growth Strategy and Development (III).

[5] Ministry of Transport and Public Works. (2017). Malawi National Transport Master Plan.
[6] Yifan, G., Yue, L., Xuyao, L., Pengzhou, L., Hongtao, W., \& Xin, W. (2017). Energy self-sufficient wastewater treatment plants: Feasibilities and Challengies. Energy Procedia, 3741 3751 .

[7] Chipofya, V. H (2010). Training System for Conceptual Design and Evaluation for Wastewater Treatment. Lappeenranta university of Technology.

[8] Carl Bro International. (1995). Sanitation Master Plan Study for City of Blantyre.

[9] Phekiso Consulting. (2017). Provision of Consultancy Services to Assess Five Treatment Sites in Blantyre.

[10] Davis, M. L. (2011). Water and Wastewater Engineering Design Principles and Practice. Michigan: Mc Graw Hill.

[11] Nikolay, M., \& Kulakov, A. (2017). Perculiarities of clarifiers' reconstruction at waste water treatment plants. MATEC Web of Conferences 112.

[12] Ahmed, S. A. (2007). FAST-TRACK EVALUATION OF A COMPACT CHEMICALLY ENHANCED-TRICKLING FILTER SYSTEM. Brazilian Journal of Chemical Engineering, 171-184.

[13] Giorgio, B., Matteo, C., \& Giuseppe, L. (2017). Towards energy self-sufficiency and integral material recovery in waste water treatment plants: Assessment of upgrading options. Journal of Cleaner Production, 1206-1218.

[14] Banga, J. (2017). Wastewater Treatment Engineering. New York: Arcler Press LLC.

[15] Wan, J., Gu, J., Zhao, Q., \& Liu, Y. (2016). COD Capture: a Feasible Option Towards Energy Self-sufficient Domestic Wastewater Treatment. Scientific Reports.

[16] Water Environment Federation (WEF) and American Society of Civil Engineers (ASCE). (2009). DESIGN OF MUNICIPAL WASTEWATER TREATMENT PLANTS WEF Manual of Practice No. 8, ASCE Manuals and Reports on Engineering Practice No. 7 Fifth Edition. Alexandria: WEF Press.

[17] Qingliang, Z., Zhong, H., Wang, K., Liangliang, W., Jinli, L., \& Yu, L. (2013). Removal and transformation of organic matters in domestic wastewater during lab-scale chemically enhanced primary treatment and a trickling filter treatment. Journal of Environmental Sciences, 59-68.

[18] Haimanot Habte, L., \& Hartmut, E. (2013). A pilot scale trickling filterwith pebble grsvel as media and its performance to remove chemical oxygen demand from synthetic brewery wastewater. Journal of Zhejiang University SCIENCE B, 924933.

[19] Marandi, R., \& Sepehr, S. M. (2011). Removal of Orange 7 Dye from Wastewater Used by Natural Adsorbent of Moringa Oleifera Seeds. American Journal of Environmental Engineering, 1-9.

[20] Gidde, M. R., Bhalerao, A. R., \& N. Malusare, C. (2012). Comparative Study of Different Forms of Moringa Oleifera Extracts for Turbidity Removal. International Journal of Engineering Research and Development, 14-21.

[21] Shirin, N., Pascual, M., Maja, H. S., Habauka, K. M., Maximilian, S. W., Fredrik, H., et al. (2018). Sticking Particles to solid surfaces using Moringa oleifera proteins as a glue. Colloids and Surfaces B: Biointerfaces. 
[22] Sotheeswaran, S., Nand, V., Matakite, M., \& Kanayathu, K. (2011). Moringa oleifera and other local seeds in water purification in developing countries. Research Journal on Chemistry and Environment, 135-138.

[23] Ashenafi, D., Samuel, S., \& Husen, A. (2018). Water purification and antibacterial efficacy of Moringa oleifera Lam. Agriculture and Food Security.

[24] Sivakumar, D. (2013). Adsorption study on municipal solid waste leachate using Moringa oleifera seed. International Environmental Science and Technology, 113-124.
[25] Jhon Jairo, F. D., Gaston, B., \& Juan Pablo Rodriguez, M. (2018). Influence of Storage Time of Moringa oleifera Seed on the Coagulant Activity Efficiency for Raw Water Treatment. Indian Journal of Science and Technology.

[26] Mohsen, D., \& Mohammad Hossein, A. (2016). The effects of the natural coagulant Moringa oleifera and alum in wastewater treatment at the Bandar Abbas Oi Refinery. Environmental Health Engineering and Management Journal, 225-230. 